Pirineos, 163: 97 a 109, JACA; 2008. ISSN 0373-2568

\title{
GRAZING AND CLIMATIC VARIABILITY IN SAJAMA NATIONAL PARK, BOLIVIA
}

\author{
K. ${ }^{1}$ YAGER, H. ${ }^{2}$ ReSNIKOWSKI \& S. ${ }^{3}$ HALloY
}

1 Department of Anthropology, Yale University. 10 Sachem Street, New Haven, CT 06511, USA.

2 Superintendencia Forestal, Santa Cruz, Bolivia.

3 Conservaton International, CBC Andes, Calle 13, Calacoto, La Paz, Bolivia.

c.e.: karina.yager@yale.edu

\begin{abstract}
Sajama National Park, the first protected area in Bolivia, includes five indigenous communities with a primary production base of pastoralism. The semi-arid region of the Central Andes is one of the most extreme areas of human occupation at 4200 meters altitude and affected by high climatic variability. This paper studies the relations between climate variability, resilience, biodiversity of pastures and pastoral production in Sajama National Park. We present a botanical study of palatable pasture herbs between two years, one humid (2006) and the other dry (2007). Thirty vascular plants were recorded. The number of species and the cover of iro (Festuca ortophylla) peak in areas of intermediate disturbance; areas that are at a medium distance from camelid corrals. On the other hand, the cover of ephemeral plants between tussocks increases in high disturbance areas. This is interpreted as a result of the tradeoff between the damage of grazing and the benefit of the fertilization produced by the herding animals. The local people clearly perceive strong impacts of climate change, combined with changes in management and human pressures. The social dynamics and production management, combined with climate warming, water reduction, and the increasing variability of surface water regimes create potential risks for the local sustainability of pastoralism.
\end{abstract}

Key words: pastures, vegetation structure, diversity-productivity, seasonal variation, variability, subtropical Andes, Bolivia, puna.

RESUMEN.- El Parque Nacional Sajama, la primer área protegida de Bolivia, incluye a cinco comunidades indígenas con una base de producción principalmente de ganadería. Esta región semi-árida de los Andes Centrales es una de las áreas más extremas de ocupación humana a 4200 metros de altura y es afectada por una alta variabilidad climática. Este trabajo considera las relaciones entre la variabilidad 
climática, resiliencia, biodiversidad de pastos y la producción ganadera en el Parque
Nacional Sajama. Presentamos un estudio botánico de las comunidades de hierbas
palatables a lo largo de dos años, uno húmedo (2006) y otro seco (2007). Se
encontraron unas 30 especies de plantas vasculares. El número de especies y la
cobertura de iro (Festuca ortophylla) llegan a un máximo a niveles intermedios de
perturbaciones, o sea a distancias intermedias entre corrales de camélidos. En cambio,
la cobertura de plantas efímeras entre matas aumenta hacia el mayor disturbio. Esto
se interpreta como una relación entre el daño producido por el pastoreo en sí vs. el
beneficio de la fertilización producida por el ganado. La gente local percibe
claramente fuertes impactos de cambios climáticos, combinados con cambios de
manejo y de presiones antrópicas. Las dinámicas sociales y manejo de producción,
combinados con el calentamiento climático, la reducción de agua, y el aumento de
variabilidad del agua superficial crean potenciales riesgos a la sostenibilidad local de
la ganadería.

Palabras claves: pasturas, estructura, diversidad-productividad, variación estacional, variabilidad, Andes subtropicales, Bolivia, Argentina, puna.

\section{Introduction}

Sajama National Park is located in the center west of Bolivia, adjacent to Lauca National Park in Chile. It was the first protected area in Bolivia (1939) and consists of 100,000 hectares of semi-arid puna and high-andean vegetation, including the highest forests in the world (Polylepis tarapacana, to $5200 \mathrm{~m}$, and permanent glaciers up to the volcanic peak of Sajama (6542 m). The park includes five indigenous communities (around 300 families) with production based mainly on camelid pastoralism; is one of the most extreme areas of human occupation, and an "experiment" in sustainable development within protected areas (MATA OLMO et al., 2007).

At the average elevation of human occupation, $4200 \mathrm{~m}$, the average temperature is $4.7^{\circ} \mathrm{C}$ and the average annual precipitation is $300 \mathrm{~mm}$. These values vary greatly from year to year but there is also a strong seasonal precipitation pattern with a short wet season and around five almost totally dry months (Fig. 1). Although there are no long-term climate records in Sajama, there are observations of high climatic variability evidenced by extreme climate events such as large snowfalls in 1997, 2002 and severe drought in 1983. Nearby Charaña climate station ( $110 \mathrm{~km}$ NNW of Sajama) demonstrates this high variability in annual and particularly winter precipitation (Fig. 2).

There are close to 200 vascular plants and some 110 vertebrates in the area, including several endemic or rare species. 
GRAZING AND CLIMATIC VARIABILITY IN SAJAMA NATIONAL PARK, BOLIVIA

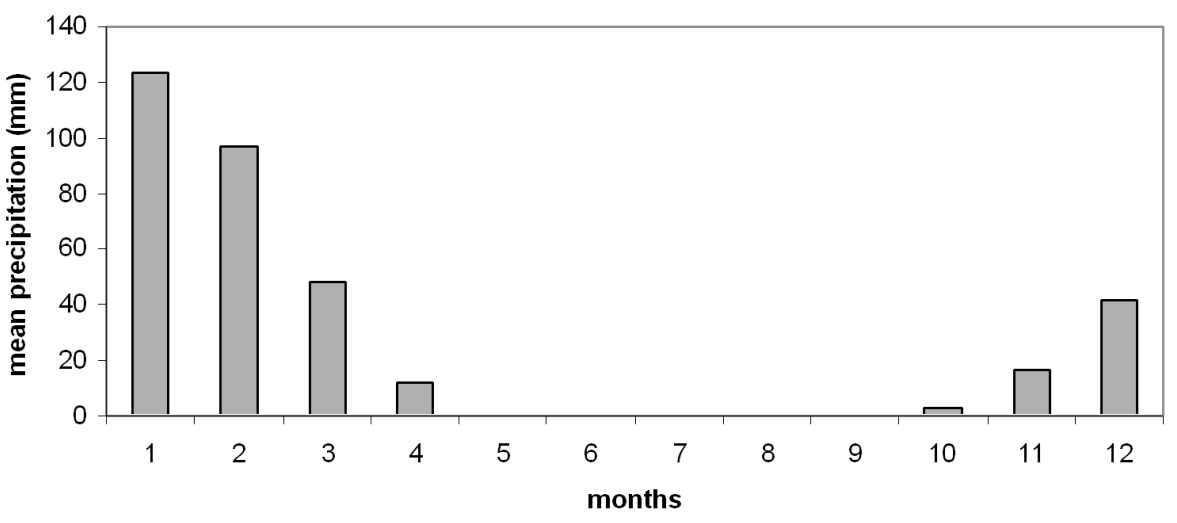

Figure 1. Annual precipitation pattern in Sajama. Data for 2005 to July 2007 graphed from SENAMHI, Bolivia.
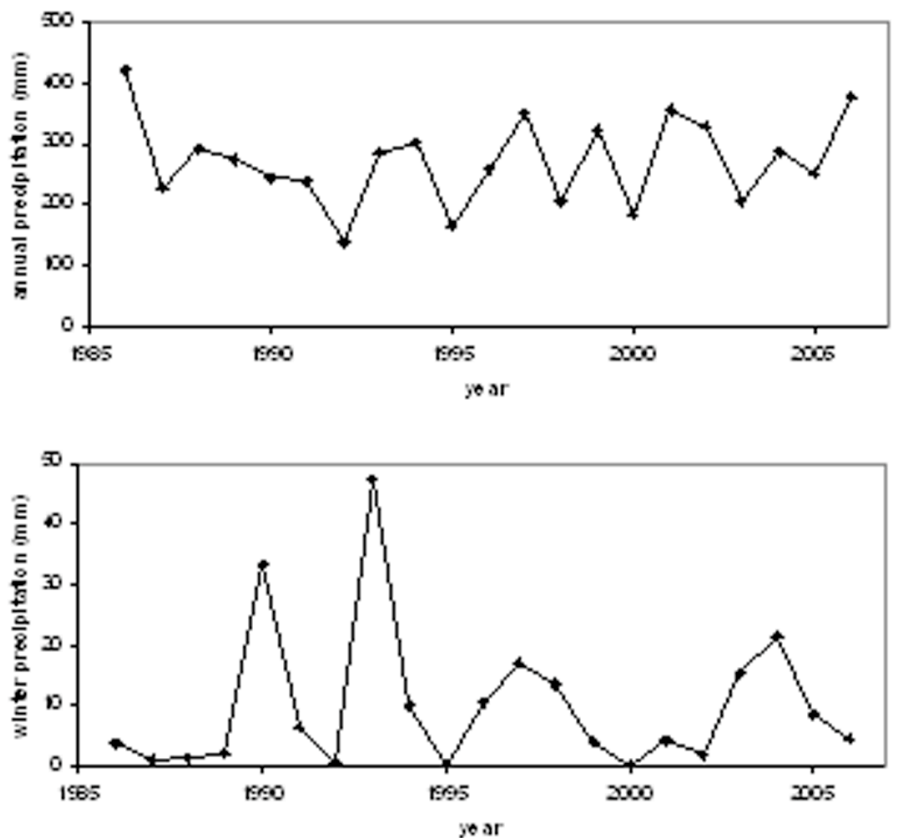

Figure 2. Multiannual variability in precipitation at Charaña. Top panel: annual totals. Bottom panel: five winter month total (May to September). Graphed from SENAMHI, Bolivia. 
A recent workshop on perception and adaptation to climate change highlighted important vulnerabilities, the main one being the primary dependency on herding (ULLOA \& YAGER, 2007). There are other activities of growing importance providing secondary household incomes, such as tourism, with an estimated 4000 visitors per year (Atkinson, 2005). Over the past three years, there has also been management of vicuña populations for wool extraction. The legal selling of vicuna wool, for the first time since the international restrictions of CITES were established to protect and recuperate the endangered populations, has instilled a new economic appreciation for these animals (fundaciónpuma.org, 2007). The vicuña population in the park is estimated at around 5000 (pers. com. Franz GUZMÁN, 2007), which compete with the domesticated camelids and sheep for scarce natural forage.

We initiated a study to ascertain the relationships between climatic variability, pasture biodiversity and camelid production in Sajama National Park, in particular comparing palatable forage herb communities between two years, one humid (2006) and the other dry (2007). Here we report the preliminary results of a study which after further work, and a greater spatial coverage, will give more definitive conclusions.

It is clear that camelids graze on the dominant tussock grass of the pajonal, the iro or Festuca orthophylla. However, we wanted to investigate the abundance and species richness, and temporal variation, of the smaller herbs that grow between the iro, and that also serve as forage. This work compliments other continuing research in the region that focuses specifically on the dynamics and productivity of iro and the smaller plants between iro (KÖRNER et al., 2007). Although iro has by far the highest biomass and plant cover, it has a very low palatability (tough, spinescent leaves with low protein content, around $6 \%$ ) compared to the intertussock plants with softer leaves and higher protein content (15-25\% protein content) (KÖRNER, pers. com., 2008).

\section{Methods}

We sampled areas of different grazing intensities, situated on lightly sloping coluvial cones of volcanic ash, around $4300 \mathrm{~m}$ in altitude, and not far $(40$ to $60 \mathrm{~m}$ ) from the humid vegetation of high Andean peat bogs (called ciénagas or bofedales). All the sample areas are dominated by a sparse grassland (3 to 19\% cover) of Festuca ortophylla (iro) with occasional tola shrubs (Parastrephia lepidophylla). During the humid summer, the ample spaces between the tussocks are occupied by low herbs, while in the dry winter season these areas are practically barren. The areas are subjected to 
variable pasture pressure and are occasionally managed with fire (more so in the past) due to recent changes in park regulations.

\subsection{Pastures}

We identified three study areas stratified over a gradient of herding intensity from very intense (close to the corrals and estancia house) to relatively disperse. These are categorized for this discussion as 'near' (60-80 $\mathrm{m}$ from the coral), 'intermediate' (120-140 m) and 'far' (180-200m). In each of the three areas we examined independently the 'inter-tussock plants' (herbaceous plants, majority ephemeral, no more than $5 \mathrm{~cm}$ tall), and the matrix of Festuca and shrubs (perennial plants, majority more than $40 \mathrm{~cm}$ tall). Both types of plants are used as forage by the camelids. The inter-tussock plants were sampled on five separate occasions to show the temporal and seasonal variation (March 2006 and in 2007 March, April, July and August). The tussocks and shrubs were measured only once (September 2007) since they don't exhibit much seasonal variation.

\subsection{Inter-tussock plants}

The vegetation between the tussocks of Festuca ortophylla (iro) was sampled by $121 \times 1 \mathrm{~m}$ quadrats (a wooden frame subdivided by a string grid into $10010 \times 10 \mathrm{~cm}$ squares), distributed as four randomly placed plots in each of the three areas stratified by grazing intensity. We evaluated the presence and cover of each species. Plants were collected outside the quadrats for identification.

\subsection{Festuca and shrub matrix}

The Festuca and shrub matrix was sampled by line intercepts (height frequency method, ALLEN et al., 1991; DICKINSON et al., 1992; SCOTT, 1965); two samples in each grazing intensity tier. A $50 \mathrm{~m}$ horizontal line was placed against the west side of six of the previous $1 \times 1 \mathrm{~m}$ quadrat samples, oriented north to south. Wherever this line intercepts a plant, the width of the intercept is noted at $0,5,10,20$, and every $10 \mathrm{~cm}$ onward up to $80 \mathrm{~cm}$ high (the maximum plant height found in this area). The projected horizontal area is calculated (corresponding to the maximum cover class), as well as the degree of overlap between strata (overlap index, calculated as the ratio between the 
sum of covers from all strata and the cover of the highest cover stratum). The only plant other than Festuca recorded in these lines was Parastrephia lepidophylla, reaching a maximum of $1.7 \%$ cover in a single sample, and therefore not considered in further analyses.

Data were processed comparing the three grazing intensities for all dates, and lumping the grazing intensities to examine the trends in seasonal variation.

\section{Results}

There are a number of studies on the management and impact of camelids in Sajama National Park in previous years (ALZÉRRECA, 2001; ESPINOZA TÉRAN, 2001a; ESPINOZA TERÁN, 2001b; ESPINOZA TERÁN, 2001c; PECA, 2002; RESNIKOWSKI, 2002), but little information exists on the capability to sustain productive capacity considering the species richness of the vegetation and the corresponding spatial and temporal variation.

\subsection{Livestock}

According to National Park census (pers. com. Franz GUZMÁN, 2007) the following livestock are present within the protected area: 24,170 llamas, 21,320 alpacas and 3,828 sheep, in addition to a nominal number of donkeys, horses and pigs.

\subsection{Spatial distribution of richness and abundance of the pasture plants}

We recorded a total of 30 vascular plants in the three study areas. Only two of these exceed $5 \mathrm{~cm}$ in height, the dense spinescent tussocks of iro (Festuca ortophylla) and the tola shrubs (Parastrephia lepidophylla). Both reach around 80 $\mathrm{cm}$ in height in our study sites, although most plants do not exceed $40 \mathrm{~cm}$.

\subsubsection{Inter-tussock Plants}

27 species of prostrate or dwarf plants were recorded in the spaces between tussocks and herbs. Most of these are probably ephemeral, completing an accelerated life cycle up to flowering and fruiting within the two or three months of the rainy season. 
These species are unequally distributed with respect to the grazing gradient (Fig. 3). The maximum species richness is attained with intermediate grazing intensity, with four times more species than far from the corrals. On the other hand, cover increases fourfold from far to near the corrals, despite grazing.

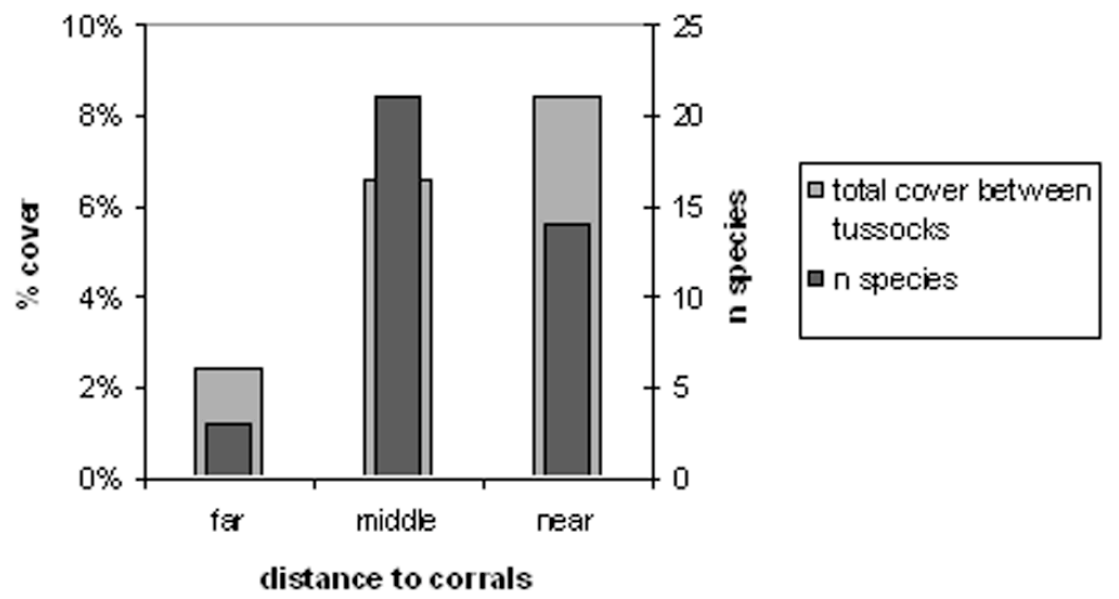

Figure 3. Species richness (dark narrow columns) and cover of herbaceous plants between iro tussocks, in relation to distance to camelid corrals.

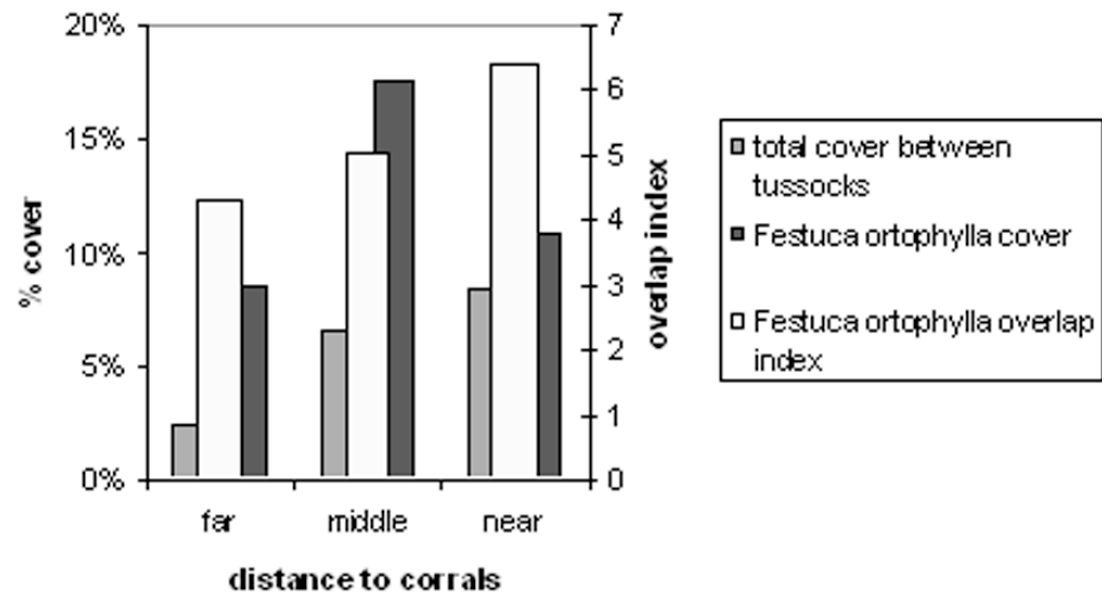

Figure 4. Cover and overlap index in relation to distance to camelid corrals. 
K. YAGER, H. RESNIKOWSKI \& S. HALLOY
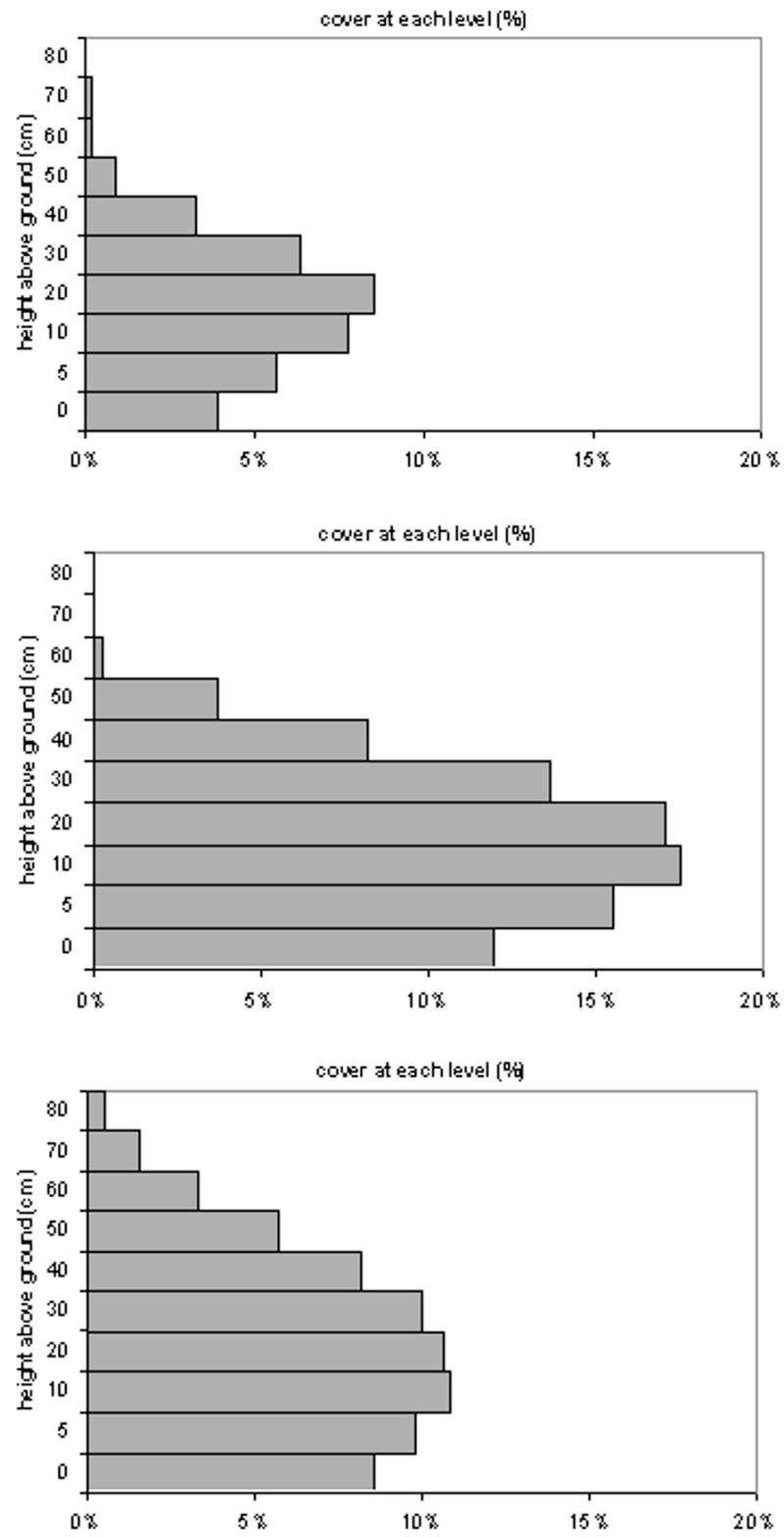

Figure 5. Average vertical structure of Festuca ortophylla tussocks in the three sampling areas: far (upper), middle (middle) and near (below). 


\subsubsection{Festuca and shrub matrix}

The overlap index for Festuca ortophylla shows a similar trend to the intertussock cover, increasing from far to near the corrals (Fig. 4). In contrast, maximum cover values peak in the intermediate grazing area, a trend which may reflect a tradeoff between the benefits of fertilization and the extraction of biomass by grazing.

Tussock vertical structure also reflects these drivers (Fig. 5). There is a maximum development of middle strata at intermediate distances of grazing disturbance. These are the strata where young growing tillers emerge. At greater distances from the disturbance of grazing, but also less fertilization, plants are clearly smaller. Close to the corrals, plants are tall, but the middle strata are reduced by grazing.

\subsection{Tempral dynamics of inter-tussock plants}

The iro and shrub matrix varies very little between seasons, and even between years. In contrast, inter-tussock plants, in addition to their spatial variation, show enormous temporal variation, from all to nothing. There is a remarkable seasonal variation (Figs. 6 and 7) between summer and winter (March 2007 to August 2007).

However, interannual variation can be much larger still (March 2006 to March 2007), reflecting substantial variations in the precipitation regime.

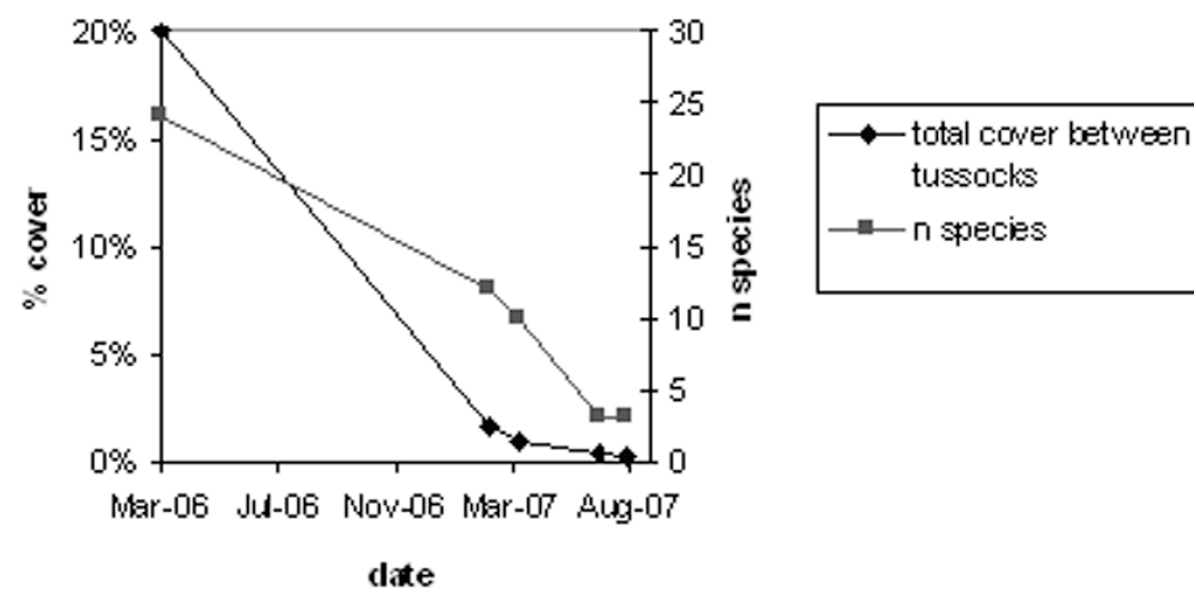

Figure 6. Temporal variation in species richness and cover between tussocks, grouping the three sampling areas. 


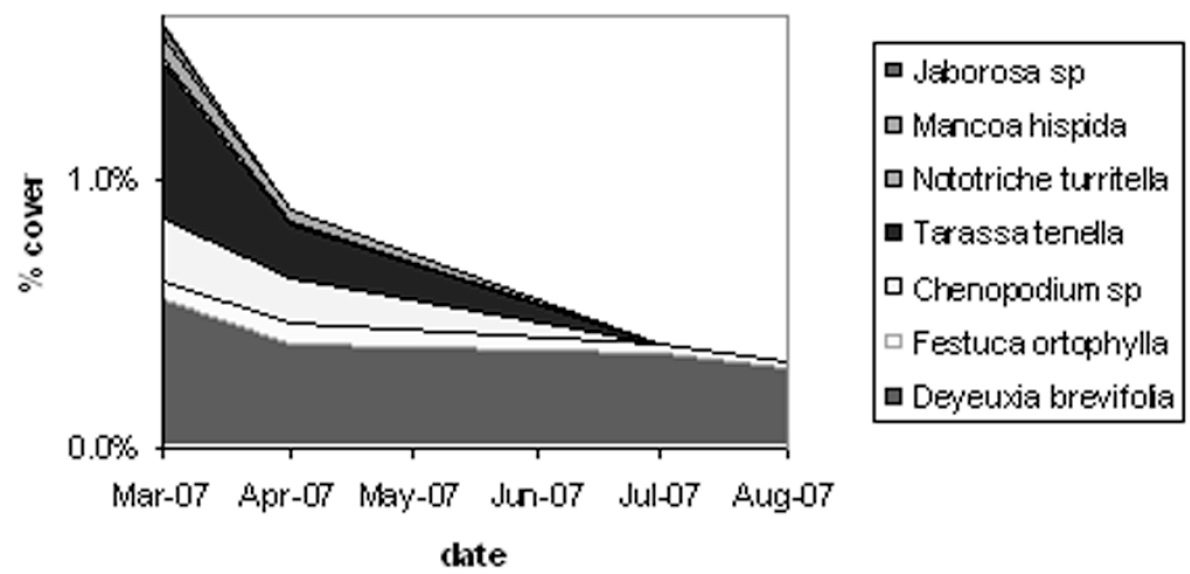

Figure 7. Temporal variation in cover of the most abundant species of the three areas sampled. The graph focuses only on data from March 2007 to observe seasonal detail.

The overall temporal variation is the result of a combination of diverse life strategies. A few perennial species maintain a relatively constant cover throughout the seasons (Fig. 7). Deyeuxia brevifolia, Festuca ortophylla and Nototriche turritella maintain an above-ground presence all year long, with some reduction in winter due to leaf senescence and grazing pressure on dormant leaves. Whereas the species of Tarassa, Mancoa, Cheopodium and several others go from being dominant in summer to completely disappearing from the surface in winter.

\section{Discussion and Conclusions}

Plant diversity between tussocks is relatively high, with up to 12-19 species per square meter (total recorded in the 12 quadrats $=27$ species, minimum 2 species in summer, 0 in winter). Cover values can be high for a semi-arid zone, up to $32 \%$. However, this varies substantially, falling to zero in winter or dry years.

There are interesting patterns relating species richness of plants (many of them palatable), their abundance, and the proximity of camelid corrals (as indicator of grazing intensity).

There are fewer species and fewer cover in quadrats farthest from the corrals, but cover is less variable, maintaining a higher cover in winter with 
palatable species such as Deyeuxia brevifolia. Quadrats closer to corrals have more species, but these are more ephemeral. Species numbers peak at intermediate distances.

Grazing pressure is compensated in two ways. Plants between tussocks are small, pressed flat against the ground, and short-lived. These features allow them to escape, at least partly, camelid predation. Secondly, fertilization from the abundant camelid droppings and urine is a strong bonus for the plants. The majority of plants recorded are known to be nitrophilous. A tradeoff is reached in the middle zone, where there is a maximum number of species, but they reach slightly lesser cover than closer to corrals with maximum fertilization.

Cumulative iro cover, the sum of all strata, (and presumably biomass) shows a unimodal distribution, as the species numbers between tussocks: a peak at intermediate disturbance where medium fertilization balances out with medium grazing. Presumably fire frequency and intensity follows a gradient similar to grazing intensity.

These relationships are descriptive and at this time largely tentative. Despite the apparent homogeneity of the terrain, there are other variables which may complicate the grazing interpretation, mainly the soil water regime and salinity.

Interannual variation is substantial, with cover values falling to an average below 10\% between 2006 and 2007. This decrease can have serious consequences for livestock nutrition. Local people report an increase in livestock deaths from 'flacura' (roughly translated as 'thinness', in other words malnutrition) during the winter of 2007. Seasonal and climatic variability push carrying capacity to minimum levels. Modeling forecasts (reduction in precipitation and increases in evapotranspiration for this region (GARCÍA CÁRDENAS et al., 2006), combine with historical variations (in water resources and the peat bog pastures (FLORES CARTAGENA, 2002), and increasing trends in population and overgrazing (ULLOA \& YAGER, 2007) to suggest that Sajama pastoral systems are approaching a major crisis in sustaining production.

\section{Acknowledgements}

We are greatly indebted for the warm help, logistic support and information provided by local communities and park guards of the Sajama National Park, particularly its director, Franz GUZMÁN, and the owner of the sampling area, René LAURA. 


\section{References}

ALLEN, R.B., LEE, W.G. \& MARK, A.F., (1991). A preliminary assessment of the effects of management on mouse-ear hawkweed (Hieracium pilosella) establishment in narrow-leaved snow tussock (Chionochloa rigida) grassland, Lammermoor Range, East Otago. In: G.G. HUNTER, C.R. MASON and D.M. ROBERTSON (Editors), Workshop of the New Zealand Ecological Society. New Zealand Ecological Society Occasional Publication, Cass Field Station, Canterbury, pp. 45-47.

ALZÉRRECA, H., (2001). Los Campos Nativos de Pastoreo en el Área del Parque Nacional Sajama y su Capacidad de Carga, MAPZA-GTZ-Parque Nacional Sajama-SERNAP, La Paz, Bolivia. 151 pp.

ATKINSON, D., (2005). Ecotourism on the rise in Bolivia. http:/ / news.bbc.co.uk/1/hi/ world/americas / 4180442.stm, 20050903

DICKINSON, K.J.M., MARK, A.F. \& LEE, W.G., (1992). Long-term monitoring of non-forest communities for biological conservation. New Zealand Journal of Botany, 30: 163-179.

ESPINOZA TERÁN, C.W., (2001a). Caracterización de los Sistemas de Producción del Parque Nacional Sajama a partir de los Estudios de Caso y la Caracterización Comunal, MAPZA-GTZ-Parque Nacional SajamaSERNAP, La Paz, Bolivia. 82 pp.

ESPINOZA TERÁN, C.W., (2001b). Caracterización de los Sistemas de Producción del Parque Nacional Sajama y la Zona de Amortiguación, MAPZA-GTZ-Parque Nacional Sajama-SERNAP, La Paz, Bolivia. 117 pp.

ESPINOZA TERÁN, C.W., (2001c). Estrategia de Desarrollo Ganadero para el Parque Nacional Sajama y Zonas de Amortiguación, MAPZA-GTZParque Nacional Sajama-SERNAP, La Paz, Bolivia. 104 pp.

FLORES CARTAGENA, D., (2002). Identificación y análisis de cambios en bofedales de la Cordillera Occidental y del Altiplano de Bolivia. Tesis Maestría Profesional en "Levantamiento de recursos hídricos (Manejo y conservación de cuencas)" Thesis, Universidad Mayor de San Simón, Internacional Institute for Infraestructural Hydraulic and Environmental Engineering, Santa Cruz.

fundaciónpuma.org, (2007). Bolivia exporta por primera vez fibra de vicuña silvestre. 20070604

GARCÍA CÁRDENAS, M., TABOADA BELMONTE, C. \& YUCRA SEA, E., (2006). Evaluación de las Tendencias del Balance Hídrico como Indicador del Cambio Climático. Programa Nacional de Cambio Climático (PNCC), La Paz, Bolivia, $43 \mathrm{pp}$.

KÖRNER, C. et al., (2007). Uso y manejo sostenible de la tierra en el Altiplano Boliviano: efectos de pastoreo y fuego sobre la productividad, biodiversidad y estabilidad del suelo. Poster at Sajama, viewed 20070527. 
MATA OLMO, R., ARROYO, R.M. \& SANTA CECILIA, F., (2007). Desarrollo rural y conservación de la naturaleza en áreas protegidas de Bolivia: la puna de Sajama (Bolivia). Anuario Europeo Americanista, 4: 1-19.

PECA H., C., (2002). Sistematización de Recursos Naturales y Biodiversidad, Gestión del Parque Nacional Sajama y Zonas de Amortiguación, MAPZAGTZ-Parque Nacional Sajama-SERNAP, La Paz, Bolivia. 86 pp $+>10$ anexos y mapas pp.

RESNIKOWSKI, H., (2002). Criterios de Planificación para el Parque Nacional Sajama, Centro de Análisis Espacial, Instituto de Ecología, Universidad Mayor de San Andrés, La Paz, Bolivia. 133 pp.

SCOTT, D., (1965). A height frequency method for sampling tussock and shrub vegetation. New Zealand Journal of Botany, 3: 253-260.

ULLOA, D., \& YAGER, K., (2007). Memorias del Taller "Cambio Climático: Percepción Local y Adaptaciones en el Parque Nacional Sajama", pp. 42. Sept. 19-20, 2007. Sajama., Conservación Internacional, Bolivia. 